\title{
First isolation of an aquatic birnavirus from farmed and wild fish species in Australia
}

\author{
Mark St. J. Crane ${ }^{1, *}$, Paul Hardy-Smith ${ }^{2, * *}$, Lynette M. Williams ${ }^{1}$, Alex D. Hyatt ${ }^{1}$, \\ Lauretta M. Eaton ${ }^{1}$, Allan Gould ${ }^{1}$, Judith Handlinger ${ }^{3}$, Jackie Kattenbelt ${ }^{1}$, \\ Nicholas Gudkovs ${ }^{1}$
}

\footnotetext{
${ }^{1}$ Australian Animal Health Laboratory, CSIRO Livestock Industries, Private Bag 24, Geelong, Victoria 3220, Australia

${ }^{2}$ Department of Primary Industries, Water and Environment, 13 St Johns Avenue, Newtown, Tasmania 7008, Australia

${ }^{3}$ Mount Pleasant Laboratories, Department of Primary Industries, Water and Environment, PO Box 46, Kings Meadows, Tasmania 7249, Australia
}

\begin{abstract}
During routine sampling and testing, as part of a systematic surveillance program (the Tasmanian Salmonid Health Surveillance Program), an aquatic birnavirus was isolated from 'pinhead' (fish exhibiting deficient acclimatisation on transfer to saltwater) Atlantic salmon Salmo salar, approximately 18 mo old, farmed in net-pens located in Macquarie Harbour on the west coast of Tasmania, Australia. The isolate grows readily in a range of fish cell lines including CHSE-214, RTG-2 and BF-2 and is neutralised by a pan-specific rabbit antiserum raised against infectious pancreatic necrosis virus (IPNV) Ab strain and by a commercial pan-specific IPNV-neutralising monoclonal antibody. Presence of the virus was not associated with gross clinical signs. Histopathological examination revealed a range of lesions particularly in pancreatic tissue. The virus was localised in pancreas sections by immunoperoxidase staining using the polyclonal antiserum and by electron microscopy. Examination by electron microscopy demonstrated that the virus isolated in cell culture (1) belongs to the family Birnaviridae, genus Aquabirnaviridae; (2) was ultrastructurally and antigenically similar to virus identified in the index fish; (3) is related to IPNV. Western blot analysis using the polyclonal rabbit antiserum confirmed the cross-reactions between various aquatic birnavirus isolates. In addition, PCR analysis of isolated viral nucleic acid from the index case indicated that the virus is more closely related to IPNV fr21 and N1 isolates than to other birnavirus isolates available for comparison. Sampling of other fish species within Macquarie Harbour has demonstrated that the virus is present in several other species of fish including farmed rainbow trout Oncorhynchus mykiss, wild flounder Rhombosolea tapirina, cod Pseudophycis sp., spiked dogfish Squalus megalops and ling Genypterus blacodes.
\end{abstract}

KEY WORDS: Virus isolation · Aquatic birnavirus · Farmed fish · Wild fish · Australia $\cdot$ Infectious pancreatic necrosis $\cdot \mathrm{IPNV} \cdot \mathrm{PCR}$

Resale or republication not permitted without written consent of the publisher

\section{INTRODUCTION}

The Tasmanian Atlantic salmon industry was founded in the early 1980s using progeny derived from Atlantic salmon farmed at Gaden, New South Wales, Australia. The Gaden stock was derived from eggs imported from Nova Scotia, Canada in the 1960s. Eyed ova were

\footnotetext{
*E-mail: mark.crane@li.csiro.au

${ }^{* *}$ Present address: Heritage Aquaculture Suite \#203, 919 Island Highway, Campbell River, British Columbia V9W 2C2, Canada
}

transferred to Tasmania from Gaden, after extensive testing for bacterial and viral pathogens, carried out over several years at the Australian Fish Health Reference Laboratory (AFHRL), Benalla, Victoria (now the AAHL Fish Diseases Laboratory located at CSIRO Livestock Industries, Geelong, Victoria). All tests demonstrated that the Gaden stock were free from recognised major pathogens of salmonids. Once in Tasmania, the fish were retained in quarantine facilities while testing continued. Only progeny from the original fish were released from quarantine, and in early 1985 the first fish were introduced into a marine 
site. Following the success with Atlantic salmon, rainbow trout, successfully introduced much earlier (in late 1800s) into Tasmania, were also subsequently grown in sea-cage sites. Over the years, the farmed salmonid industry in Tasmania has grown steadily and currently produces around 8000 metric tons of farmed product valued at approximately A $\$ 70$ million.

The farmed salmonid industry in Tasmania has not experienced any disease outbreak caused by viral pathogens. In 1990, as a result of the introduction of an active health surveillance program, a reovirus was isolated which has been shown to be non-pathogenic to young salmon (J. D. Humphrey \& J.H. pers. obs.). Ever since its first isolation, the reovirus has been detected irregularly during routine health surveillance and does not appear to be associated with any clinical disease. Extensive testing over the last $15 \mathrm{yr}$ or so, using international protocols for virus isolation, has not revealed the presence of any other virus in Tasmanian Atlantic salmon populations nor in populations of rainbow trout included in the health certification testing. Although epizootic haematopoietic necrosis virus (EHNV) is present in waterways of Victoria and New South Wales (Whittington et al. 1996), it appears that control of fish movements to Tasmania has been successful in maintaining Tasmania's EHNV-free status.

Other salmonid viruses in the Australasian region include an aquatic birnavirus, related to infectious pancreatic necrosis virus (IPNV), serotype $\mathrm{Ab}$, which was isolated in 1987 from New Zealand chinook salmon Oncorhynchus tshawtscha returning from the sea (Tisdall \& Phipps 1987). This virus was not associated with any clinical signs of disease. Subsequently, aquatic birnavirus has been isolated from New Zealand chinook salmon on several occasions (Anderson 1995).

Active surveillance of all farmed salmonid populations is undertaken as part of the Tasmanian Salmonid Health Surveillance Program which has been in place for several years. Most Tasmanian salmonid farming occurs in the south east of the State, other areas including Macquarie Harbour on the west coast, and some operations in the north of the State (Fig. 1). The program involves regular farm inspections and collection of samples for histopathology, bacteriology and virology.

In late December 1997, tissue samples were taken from 18 mo old 'pinhead' Atlantic salmon collected from a sea-cage site in Macquarie Harbour. 'Pinheads' are fish which, when transferred from fresh to brackish or salt water, struggle to acclimatise, become inappetant, and virtually cease growing. These fish are not productive and are usually culled from the sea-cages as part of normal farming practices. This report describes the isolation and preliminary identification of an aquatic birnavirus originally isolated from these fish and subsequently isolated from several other wild and farmed fish species inhabiting Macquarie Harbour.
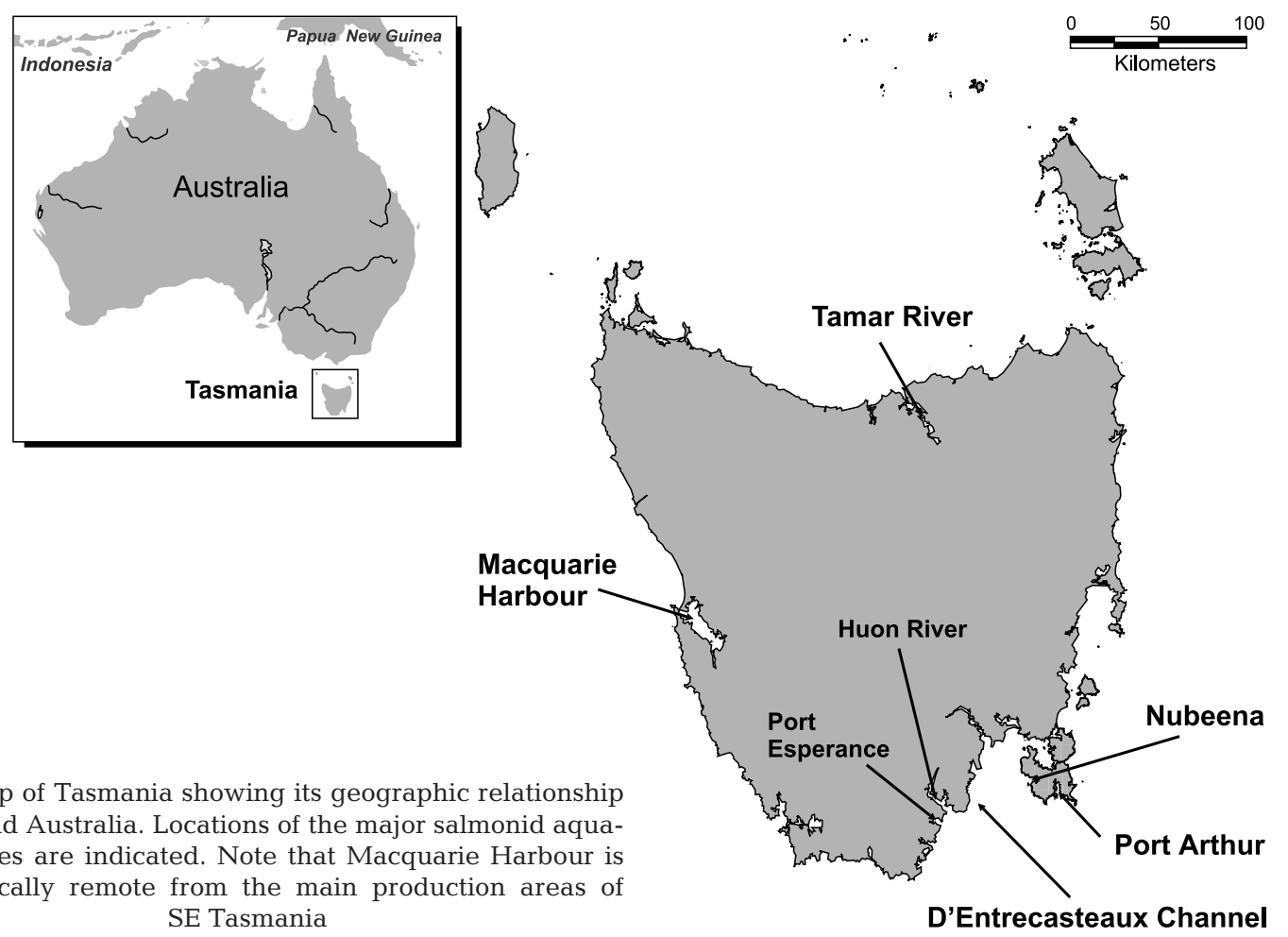

Fig. 1. Map of Tasmania showing its geographic relationship to mainland Australia. Locations of the major salmonid aquaculture sites are indicated. Note that Macquarie Harbour is geographically remote from the main production areas of SE Tasmania 


\section{MATERIALS AND METHODS}

Fish sampling. Regular, routine visits are made by State Government fish veterinarians to all salmonid farms in Tasmania as part of the Tasmanian Salmonid Health Surveillance Program. During one such visit in December 1997, to a farm located in Macquarie Harbour, 5 'pinhead' fish were collected randomly from a cage (population size of approx. 15000) of young (approx. 18 mo old) Atlantic salmon, among which there were a number of pinheads. These fish had signs that included inappetance, lethargy and elongation of the body with no increase in weight, hence causing the head of the fish to appear disproportionately large. Samples of liver, kidney, heart and spleen were collected aseptically from each fish and pooled. Routine virology sampling is augmented by opportunistic sampling of fish which are sick or in poor condition, in which case samples may be stored, as were these samples, at the local Government laboratory (at $-80^{\circ} \mathrm{C}$ ) before being forwarded to the CSIRO Australian Animal Health Laboratory for virological examination. Tissue samples including liver, kidney, spleen, pyloric caecae, pancreas, muscle, skin and heart were also taken from 2 of the 5 fish, fixed in neutral phosphatebuffered formal $(10 \%)$ saline and forwarded separately to the local State laboratory for histopathological examination.

Later, further samples were taken from other farmed fish (Atlantic salmon and rainbow trout) in the Harbour and also from various species of wild fish, both from inside and outside Macquarie Harbour (see Table 1). Samples were also collected for histopathological examination as described above. For farmed fish, a minimum of 30 fish were randomly collected from different cages at 4 separate sites in the Harbour. Most fish sampled appeared clinically normal. At no time was an increase in mortality observed in farmed fish at any of the sites. Within the Harbour wild fish were collected from 7 sites, by using either a hand-line or gill nets. Three of these sites were located near the farmed fish. The number of wild fish sampled outside the Harbour was lower due to the difficulty in collecting these fish.

Histopathology. Sections for histopathology were prepared from formalin-fixed tissues by routine dehydration through alcohol, paraffin embedding, sectioning (3 to $4 \mu \mathrm{m})$, and staining with haematoxylin and eosin.

Virus isolation on fish cell cultures. The pooled tissue samples were processed for virus isolation within $24 \mathrm{~h}$. Using standard procedures (OIE 1997), 24-well cluster plate monolayer cultures (at $90 \%$ cell confluency) of CHSE-214 (chinook salmon embryo cell line; ATCC CRL 1681), RTG-2 (rainbow trout gonad cell line; ATCC CCL 55) and EPC (epithelioma papulosum cyprini; Fijan et al. 1983) cell lines were used as host cells. Aliquots ( $150 \mu \mathrm{l})$ of 1:10 and 1:100 dilutions of the tissue homogenate were inoculated onto duplicate cultures $\left(2 \mathrm{~cm}^{2}\right.$ surface area $\left.{ }^{-1}\right)$ of each cell line. The inoculum was adsorbed for $1 \mathrm{~h}$ at $15^{\circ} \mathrm{C}$. After adsorption, $1.5 \mathrm{ml}$ Eagle's minimum essential medium, containing Earle's salts, $2 \%(\mathrm{v} / \mathrm{v})$ foetal bovine serum and $100 \mathrm{IU} \mathrm{ml}^{-1}$ penicillin and $100 \mu \mathrm{g} \mathrm{ml}^{-1}$ streptomycin (EMEM) for CHSE-214 and RTG-2 cells and Leibovitz's L-15 medium containing $2 \%$ foetal bovine serum and $100 \mathrm{IU} \mathrm{ml}^{-1}$ penicillin and $100 \mathrm{\mu g} \mathrm{ml}^{-1}$ streptomycin (L-15) for EPC cells, was added per well to yield final dilutions of 1:100 and 1:1000. Cultures were then incubated at $15^{\circ} \mathrm{C}$ in either normal atmosphere (EPC cultures in L-15) or an atmosphere of $5 \%$ $\mathrm{CO}_{2} / 95 \%$ air (cultures in EMEM). At 7 d post-inoculation (p.i.), material from cultures displaying cytopathic effect (CPE) was passaged (first passage) on to fresh cell cultures which were incubated as detailed above.

For cultures displaying $\mathrm{CPE}$, the tissue culture supernatant fluids and cells were pooled from 4 wells, filtered through 0.22 or $0.45 \mu \mathrm{m}$ membrane filters (Sartorius) and samples inoculated onto 4 wells of fresh $(24 \mathrm{~h}$ old) CHSE-214 cell cultures (second passage). When CPE was evident (at 2 d p.i.), tissue culture supernatants from these cultures were passed onto 24 -well plates containing Thermanox ${ }^{\mathrm{TM}}$ coverslips with monolayers of CHSE-214 cells attached (third passage). When CPE developed (at $3 \mathrm{~d}$ p.i.), the coverslip cultures were fixed and processed for electron microscopy. Cell cultures from this passage were also used for immunoperoxidase tests using a rabbit polyclonal antiserum raised against IPNV (A.D.H. unpubl. results).

Electron microscopy. Negative contrast electron microscopy: Cell culture supernatant fluids from CHSE-214 cell cultures exhibiting CPE were adsorbed to parlodion-filmed, carbon-coated 400 mesh copper grids. The adsorbed material was then stained with $2 \%$ (w/v) phosphostungstic acid ( $\mathrm{pH}$ 6.5).

Preparation of ultrathin samples: Coverslip cultures of CHSE-214 cells were fixed (40 min) in $2.5 \%(\mathrm{v} / \mathrm{v})$ glutaraldehyde in $0.1 \mathrm{M}$ cacodylate buffer ( $\mathrm{pH} 7.2$ ), washed $(3 \times 20 \mathrm{~min})$ in the same buffer, post-fixed in $1 \%(\mathrm{w} / \mathrm{v})$ osmium tetroxide $(1 \mathrm{~h})$, rinsed $(3 \times 5 \mathrm{~min})$ in water and dehydrated through a graded series of ethanol (20 min each). Specimens were then infiltrated and embedded in Spurr's epoxy resin. Sections were cut on a Leica-Reichart ultracut IIE and stained in uranyl acetate and lead citrate. Control cells consisted of uninfected CHSE-214 cells.

Formalin-fixed tissues that had been processed through to paraffin blocks were processed for electron microscopy. The tissues originated from Atlantic salmon displaying pancreatic lesions. Paraffin sections $(12 \mu \mathrm{m})$ were processed through to Spurr's epoxy resin 
(as above) or LR White resin (Hyatt 1991). Sections embedded in Spurr's resin were used for ultrastructural examination and those embedded in LR White resin were used for immunoelectron microscopy (Hyatt 1991).

Immunoelectron microscopy: Virus preparations adsorbed to copper grids (as above) were incubated in $1 \%(v / v)$ cold-water fish skin gelatin (Sigma \#G7765) in phosphate buffered saline (PBS; $\mathrm{pH} 7.4$ ) for $10 \mathrm{~min}$, and then incubated for $1 \mathrm{~h}$ (at $24^{\circ} \mathrm{C}$ ) with rabbit polyclonal antiserum (diluted 1:800) raised against IPNV, serotype Ab (Hyatt et al. unpubl. results). The preparations were washed in PBS $(6 \times 3 \mathrm{~min})$ and then incubated in protein A-gold (Hyatt 1991) for $1 \mathrm{~h}$ (1:100, $24^{\circ} \mathrm{C}$ ), washed in PBS and stained in phosphotungstic acid.

Ultrathin sections of the $12 \mu \mathrm{m}$ sections were cut and processed as follows. Sections were washed in PBS (3 min) and then incubated with $1 \%(\mathrm{v} / \mathrm{v})$ cold-water fish skin gelatin in PBS for $10 \mathrm{~min}$. Sections were then placed in humid incubation chambers (Hyatt 1989, 1991) and incubated with the above antisera (diluted 1:800 in PBS) for $2 \mathrm{~h}$ at $24^{\circ} \mathrm{C}$. Sections were then washed with PBS $(6 \times 3 \mathrm{~min})$ and incubated with protein A-gold (diluted 1:100) at $24^{\circ} \mathrm{C}$. Sections were subsequently washed with PBS, post-fixed with $2.5 \%$ cacodylate-buffered glutaraldehyde (5 min), rinsed in water $(3 \times 3 \mathrm{~min})$ and stained (refer above).

All specimens were examined at either 75 or $100 \mathrm{kV}$ with a Hitachi H7000 scanning transmission electron microscope, calibrated with a 2160 lines $\mathrm{mm}^{-1}$ grating replica.

Virus neutralisation. Virus neutralisation was carried out using 96-well cultures of CHSE-214 cells, the polyclonal rabbit antiserum raised against IPNV, serotype $\mathrm{Ab}$, and the monoclonal antibody AS1 (DiagXotics Inc. USA \#93-AS1UC), which is pan-specific and neutralising for all aquatic birnaviruses tested to date. Normal rabbit serum and the pan-specific, non-neutralising monoclonal antibody E5 (DiagXotics Inc. \#93-E5UC) were used as negative controls. Each of the antibody preparations were titrated in a $10 \times$ dilution series. Approximately $200 \mathrm{TCID}_{50}$ of each virus (IPNV serotype $\mathrm{Ab}$ or the Tasmanian isolate) was added to each antibody dilution, incubated at room temperature (approximately $22^{\circ} \mathrm{C}$ ) for $1 \mathrm{~h}$, and added to CHSE-214 96-well cultures which were then incubated at $15^{\circ} \mathrm{C}$. At 2 to $3 \mathrm{~d}$ intervals, post-inoculation, cultures were examined by light microscopy for development of viral CPE.

Immunoperoxidase tests. Histological sections: Formalin-fixed tissues were dehydrated and processed through to paraffin blocks using standard procedures. For each experiment, sections of uninfected negative control tissues from fish originating from Victoria, Australia, positive control tissues from a natural outbreak of infectious pancreatic necrosis in brook trout fry in Germany (kindly donated by Dr H. J. Schlotfeldt, State Fish Epidemics Control Service of Lower Saxony, Hannover, Germany) and tissues from Tasmanian Atlantic salmon displaying pancreatic lesions were included. Following deparaffinisation, the sections were incubated with a trypsin (1:250; Difco \#0152-15) solution (1 mg ml $\mathrm{m}^{-1}$ trypsin; $0.1 \mathrm{M}$ Tris/ $\mathrm{HCl}_{i} 1 \mathrm{mg} \mathrm{ml}^{-1}$ $\mathrm{CaCl}_{2} ; \mathrm{pH} 8.0$ ) for $20 \mathrm{~min}$ at $37^{\circ} \mathrm{C}$. The reaction was stopped using cold $\left(4^{\circ} \mathrm{C}\right)$ phosphate-buffered saline (PBS without $\mathrm{Ca}^{2+}$ and $\mathrm{Mg}^{2+}$ ions; $\mathrm{pH} 7.4$ [PBSA]). Sections were then incubated for $1 \mathrm{~h}$ at $37^{\circ} \mathrm{C}$ with either rabbit polyclonal antiserum (A.D.H. unpubl. results) to IPNV serotype Ab (Hill \& Way 1995) or normal rabbit serum (NRS) diluted 1:1000 in 1\% (w/v) skim milk in PBSA. After washing in PBSA, the sections were incubated for $1 \mathrm{~h}$ at $37^{\circ} \mathrm{C}$ with biotinylated donkey antirabbit Ig (Amersham \#RPN 1004) diluted 1:200 with $0.1 \%$ (w/v) skim milk in PBSA. After washing in PBSA, the sections were immersed in $3 \%(\mathrm{v} / \mathrm{v})$ peroxide solution in methanol for $20 \mathrm{~min}$ at room temperature to block any endogenous peroxidase activity. Following a wash in PBSA, the sections were incubated for $1 \mathrm{~h}$ at $37^{\circ} \mathrm{C}$ with streptavidin-horseradish peroxidase (Amersham \#RPN 1231) diluted 1:300 in $0.1 \%(\mathrm{w} / \mathrm{v})$ skim milk in PBSA. Following a further wash in PBSA, the sections were incubated with freshly prepared substrate (3 amino-9-ethyl carboxyzole [AEC]; Sigma \#A5754) solution ( $2 \mathrm{mg}$ AEC, $200 \mu \mathrm{l}$ dimethylformamide [BDH \#10322], $10 \mathrm{ml} 0.05 \mathrm{M}$ acetate buffer $\mathrm{pH}$ 5.0, $5 \mu \mathrm{l}$ $30 \%$ [v/v] hydrogen peroxide [BDH \#10366]) for $20 \mathrm{~min}$ at room temperature. The sections were rinsed in tap water, counterstained with Mayer's haematoxylin and mounted in GelTol ${ }^{\mathrm{TM}}$ (Immunon \#484945) for microscopic examination.

Cell cultures: Cell cultures for immunoperoxidase tests were fixed in $10 \%(\mathrm{v} / \mathrm{v})$ formalin in PBSA, rinsed with PBSA and stored under PBSA at $4{ }^{\circ} \mathrm{C}$ until use. For each experiment, IPNV-infected positive control cultures and uninfected negative control cultures were included.

Fixed cultures were rinsed with PBST (PBSA with $0.05 \%$ [v/v] Tween 20) and incubated for $1 \mathrm{~h}$ at $37^{\circ} \mathrm{C}$ in a humidified chamber with rabbit polyclonal antiIPNV antiserum or NRS diluted $1 / 1000$ in $1 \%(\mathrm{w} / \mathrm{v})$ skim milk powder in PBSA. The procedure was the same as described above for tissue sections except that PBST was used for the washes between incubation steps.

In addition, a series of monoclonal antibodies obtained from DiagXotics Inc. were used in the immunoperoxidase test to compare the patterns of reactivity of the Tasmanian isolate with IPNV reference strains Ab, Sp, VR-299 and Erwin (obtained from CEFAS Weymouth Laboratory, UK. 
Western blotting. Viral isolate 980047 (from the index case) was compared with plaque-purified IPNV reference serotypes Ab, Sp and VR-299. Cell culturederived virus was resuspended in SDS-PAGE sample buffer $(0.0625 \mathrm{M}$ Tris/ $\mathrm{HCl}, 10 \%$ glycerol, $2.3 \%$ SDS, $5 \% \beta$-mercaptoethanol, $\mathrm{pH} 6.8)$. Samples were then treated at $100^{\circ} \mathrm{C}$ for $5 \mathrm{~min}$ to solubilise viral and other associated proteins and stored at $-20^{\circ} \mathrm{C}$ before electrophoresis.

Viral proteins were analysed by Western blot following electrophoresis using the buffer system of Laemmli (1970). Viral proteins were resolved in $12 \%(\mathrm{w} / \mathrm{v})$ acrylamide gels overlayed with a $4.75 \%$ (w/v) stacking gel. Piperazine di-acrylamide was substituted for $\mathrm{N}, \mathrm{N}^{\prime}$-methylene-bis-acrylamide on a weight for weight basis, the final concentration of cross-linker being $2.67 \%$ with respect to total acrylamide. Following electrophoresis, proteins were transferred to $0.22 \mu \mathrm{m}$ nitrocellulose sheets (NitroPure, Micron Separations Inc. \#WP2HY00010) at $30 \mathrm{~V}$ for $16 \mathrm{~h}$ at $4^{\circ} \mathrm{C}$ using the buffer system of Towbin et al. (1979).

The transferred viral proteins were probed with both pre-immune and hyper-immune polyclonal antisera raised against IPNV serotype Ab, IHNV, VHSV or Tasmanian aquareovirus. The membranes were blocked for $30 \mathrm{~min}$ with $3 \%(\mathrm{w} / \mathrm{v})$ skim milk (SM) in $0.01 \mathrm{M}$ Tris- $\mathrm{HCl} \mathrm{pH} 7.4,0.15 \mathrm{M} \mathrm{NaCl}$ (SM solution) at room temperature. The blocking solution was discarded and the membranes were reacted with the sera diluted 1:500 in SM solution and incubated at room temperature on a slow-speed flat-bed orbital shaker for $1 \mathrm{~h}$. The membranes were washed ( $5 \mathrm{~min}$ ) twice with $0.01 \mathrm{M}$ Tris-HCl pH 7.4, $0.15 \mathrm{M} \mathrm{NaCl}, 0.05 \%$ (v/v) Tween 20, followed by a final wash of $10 \mathrm{~min}$ in $0.01 \mathrm{M}$ Tris- $\mathrm{HCl}$ $\mathrm{pH} 7.4,0.15 \mathrm{M} \mathrm{NaCl}$. All membranes were then incubated with freshly prepared anti-rabbit, horseradish peroxidase (HRPO) conjugate (Silenus \#RAH) diluted at 1:500 with SM solution using the same incubation conditions used for the primary antibody step. The membranes were washed again as described previously and developed using 4-chloro-1-naphthol as substrate at room temperature for 15 to $30 \mathrm{~min}$ to obtain optimal staining with a minimum of background. The substrate was prepared by dissolving $60 \mathrm{mg} 4$-chloro1-naphthol in $20 \mathrm{ml}$ methanol on ice; just before use this was mixed with $100 \mathrm{ml}$ in $0.01 \mathrm{M}$ Tris- $\mathrm{HCl} \mathrm{pH} \mathrm{7.4,}$ $0.15 \mathrm{M} \mathrm{NaCl}$ to which $60 \mu \mathrm{l}$ of $30 \%$ (v/v) $\mathrm{H}_{2} \mathrm{O}_{2}$ had been previously added. Images of Western blots were digitised with a UMAX Powerlook II scanner. Approximate molecular weights of viral proteins were determined by comparison with molecular weight standards (Biorad \#161-0305) using Kodak Digital Science 1D software.

Nucleic acid purification, PCR analysis and sequence analysis. Nucleic acids from supernatant fluid from virus-infected cell cultures was extracted with phenol:chloroform $(1: 1 \mathrm{v} / \mathrm{v})$, ether extracted and then precipitated by 2.5 volumes of ethanol in the presence of $0.3 \mathrm{M}$ sodium acetate at $-80^{\circ} \mathrm{C}$. The precipitate was collected by centrifugation $(10000 \times g)$ and dried under vacuum. This nucleic acid preparation was dissolved in water, heated for 2 min in RNAse-free (diethylpyrocarbonate-treated) water and immediately quenched on ice. cDNA was immediately transcribed from the denatured nucleic acid in a total volume of $20 \mu \mathrm{l}$ by adding DNA primer (TAB-1; $5 \mu \mathrm{M})$, dNTPs $(0.125 \mathrm{mM}$ each), in $50 \mathrm{mM}$ Tris- $\mathrm{HCl}(\mathrm{pH} 8.3), 75 \mathrm{mM} \mathrm{KCl}, 3 \mathrm{mM} \mathrm{MgCl}_{2}$, $10 \mathrm{mM}$ dithiothreitol, 20 units AMV reverse transcriptase (Promega) and 40 units RNAse inhibitor (Promega) and incubating at $42^{\circ} \mathrm{C}$ for $60 \mathrm{~min}$. cDNA (1 $\left.\mu \mathrm{l}\right)$ was then amplified in a total reaction volume of $50 \mu \mathrm{l}$ with oil overlay using the following conditions. $10 \mathrm{mM}$ Tris- $\mathrm{HCl}$ (pH 8.8), $50 \mathrm{mM} \mathrm{KCl}, 2.5 \mathrm{mM} \mathrm{MgCl}_{2}, 0.05 \mathrm{mM}$ (each) dNTPs, $200 \mathrm{mM}$ each primer (TAB-1 and TAB-2) and 0.25 units Taq polymerase (Promega) were incubated in a Perkin Elmer thermocycler for 25 cycles consisting of $1 \mathrm{~min}$ at $94^{\circ} \mathrm{C}, 2 \mathrm{~min}$ at $37^{\circ} \mathrm{C}$ and $2 \mathrm{~min}$ at $74^{\circ} \mathrm{C}$ for each cycle. The PCRs were incubated for a further $15 \mathrm{~min}$ at $74^{\circ} \mathrm{C}$ after completion of the cycling reaction and then electrophoresed through a $1 \%$ TAEagarose gel containing ethidium bromide. DNA bands were visualised using UV irradiation, excised from the gel and purified using the QIAquick extraction system (Qiagen) according to the manufacturer's instructions. DNA ( 450 bp) was eluted from the column into a total volume of $30 \mu \mathrm{l}$ water and sequenced using an ABI Prism 377 automated sequencer (Perkin Elmer) and the manufacturer's BIG DYE fluorescent dye chemistry with primers TAB-1 and TAB-2. DNA sequences were analysed using Clone Manager and Align programs (Scientific and Educational Software) while Clustal V (PCGene suite of programs, Intelligenetics) or the PHYLIP programs (Felsenstein 1989) using Protpars and DNApars were used to estimate phylogenies using the parsimony method. Sequences of the primers TAB1 and TAB-2 were 5'-GGTCTCAACTATGCCAAGATGAT and 5'-TGTGCACCACAGGAAAGATGACTC, respectively, which flanked a hypervariable region on segment A from nucleotides 1317 to 1738.

\section{RESULTS}

\section{Histopathology}

A diffuse, predominantly mononuclear inflammatory infiltrate was observed in the pancreas of both fish sampled in the index case. Pancreatic fat was negligible in both fish, so that fat cell nuclei compounded the increase in cellularity; however, they could usually be 
clearly distinguished. In 1 fish, mononuclear inflammatory cells infiltrated and separated pancreatic acinar cells. There was no overt acinar cell necrosis (Fig. 2A). Both fish showed mild skeletal muscle degeneration with concentric splitting and central nuclei in a few fibres (Fig. 2B). In 1 fish, there was phagocytosis of necrotic fibres by macrophages. There was increased pigment, consistent with catabolism, in both kidneys. No significant lesions were observed in other organs.

In subsequent samples, pancreatic necrosis and inflammation was seen only in 1 'pinhead' fish from a virus-positive pool submitted late in the following spring. This finding was regarded as equivocal, however, as this fish had a Vibrio anguillarum septicaemia which was associated with widespread inflammatory lesions in other organs. This observation created uncertainty about the cause of the pancreatic lesions. Examination included tissues from 26 Atlantic salmon, 23 rainbow trout, 5 flounder Rhombosolea tapirina, 2 cod Pseudophycis sp. and 4 spiked dogfish Squalus
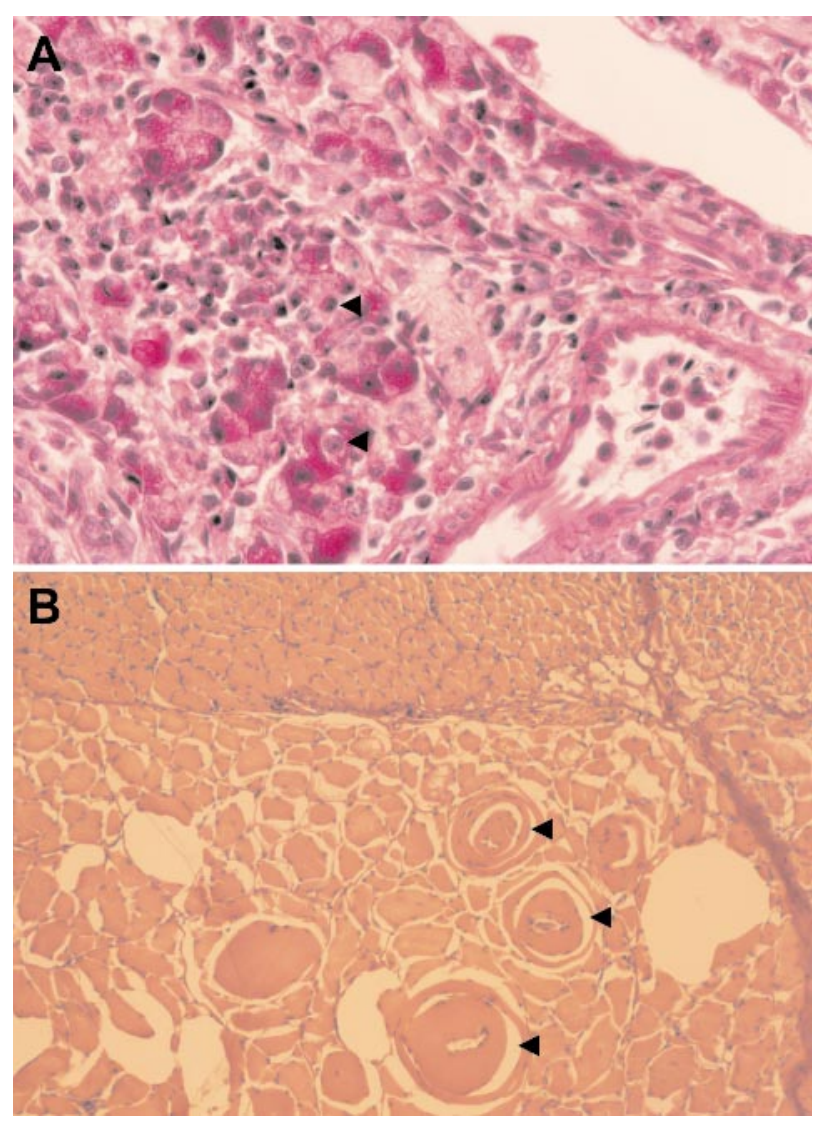

Fig. 2. Photomicrographs of histological sections of (A) pancreas and (B) skeletal muscle from the index case. Note the lesions indicated by the arrowheads showing inflammatory cells, some infiltrating and separating pancreatic acinar cells (A), and concentric muscle fibre splitting in dorso-lateral skeletal muscle (B) megalops from virus positive pools. Individual fish shown to be virus-positive and examined histologically included 2 rainbow trout, 2 Atlantic salmon, 1 cod, 1 flounder and 1 dogfish. No lesions were observed in pancreatic acinar of any of these fish. Very small inflammatory foci, more generally associated with fat or peritoneal surfaces than with acini, were seen in 2 rainbow trout and 4 Atlantic salmon from positive pools, including 1 known positive salmon and 1 known positive trout. However, these signs were also seen occasionally in virus-negative fish and may therefore have been related to other lesions. Lymphoid foci in pancreas or liver, consistent with a recent immunological response, were seen in 3 rainbow trout and 7 Atlantic salmon from positive pools, including 1 definite virus-positive salmon. Lymphoid foci were also present in the solid pancreas of all dogfish examined. No normal or confirmed negative samples of this species were available for comparison.

\section{Virus isolation on fish cell cultures}

Index case

Between 3 and 5 d p.i., viral CPE became evident in the primary cultures of CHSE-214 and RTG-2 cells inoculated with final sample dilutions of 1:100 and 1:1000 prepared from the original 5 fish sample (Fig. 3). CPE developed for $7 \mathrm{~d}$ until there was total destruction of the cell monolayer. When aliquots of this material were passed onto $24 \mathrm{~h}$ old, $90 \%$ confluent CHSE-214 cell cultures at $15^{\circ} \mathrm{C}$, viral $\mathrm{CPE}$ developed after $6 \mathrm{~d}$. When aliquots of supernatant fluids from these cultures were filtered through either 0.22 or $0.45 \mu \mathrm{m}$ filters and inoculated onto CHSE-214 cell cultures, CPE was evident $2 \mathrm{~d}$ after passage.

RTG-2 cell cultures, inoculated with the 1:100 original sample dilution, displayed sample cytotoxicity and, on passage, viral CPE did not develop. However, when tissue culture supernatant fluids from the third passage in CHSE-214 cells were inoculated onto RTG-2 cell cultures, CPE appeared after $3 \mathrm{~d}$ incubation.

EPC cell cultures did not display any CPE in the primary cultures after $7 \mathrm{~d}$ incubation at $15^{\circ} \mathrm{C}$. Material from these primary cultures was passed onto fresh EPC cultures and incubated for a further $25 \mathrm{~d}$ without any evidence of CPE.

For those cultures which did develop $\mathrm{CPE}$, the $\mathrm{CPE}$ appeared to affect the complete monolayer, often without the formation of discrete plaques, and was distinct from CPE typical of Atlantic salmon reovirus (Fig. 3). Large rounded hypertrophic cells remained attached to the plastic substrate prior to the monolayer detaching. This effect occurred at different times after pas- 


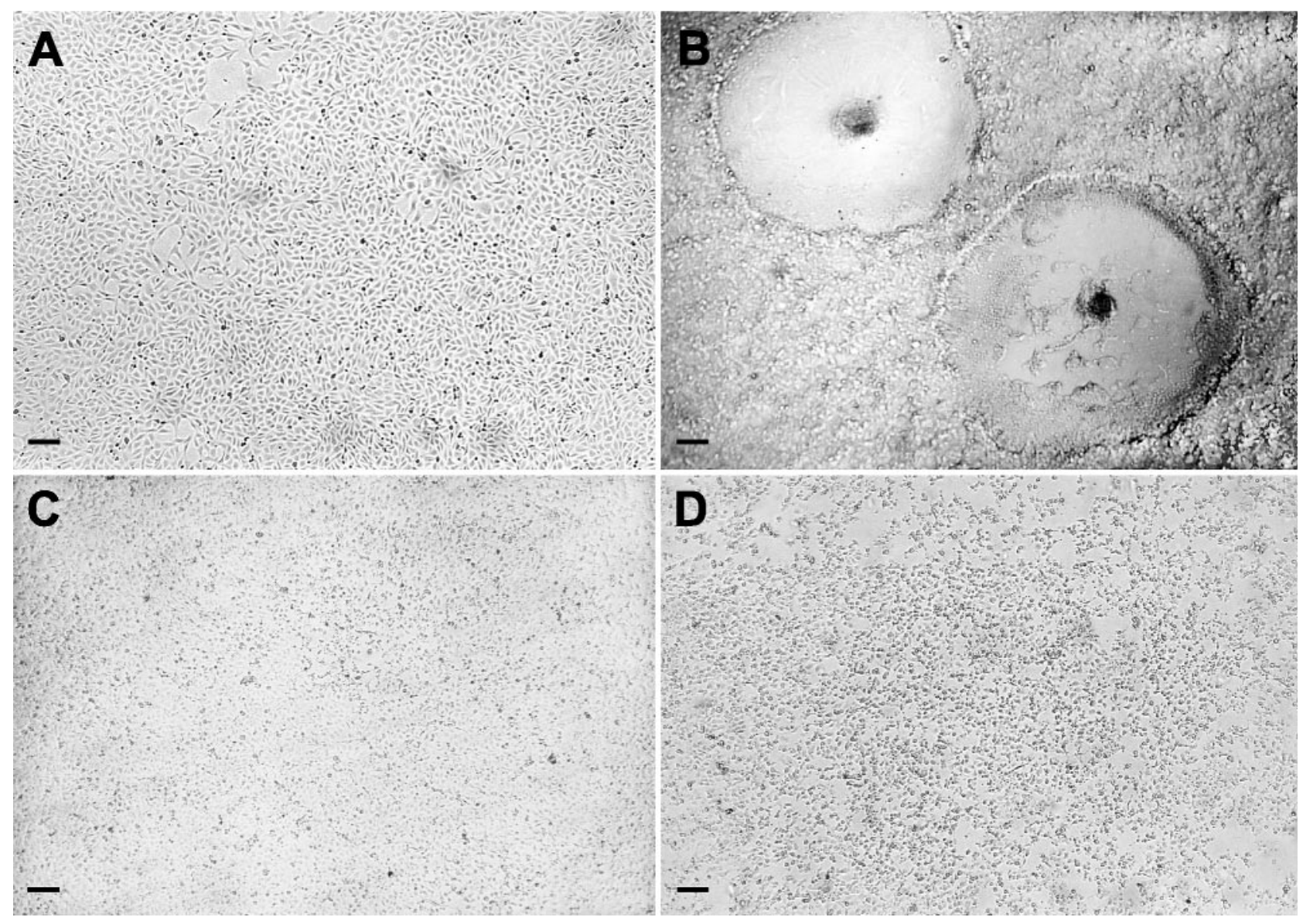

Fig. 3. Photomicrographs of CHSE-214 cell cultures. (A) Uninfected control culture at approximately $90 \%$ confluency showing normal cellular morphology. (B) Cell culture infected with Atlantic salmon reovirus at 4 d post-infection and showing typical CPE induced by Atlantic salmon reovirus infection. (C) Cell culture infected with Macquarie Harbour isolate 980047 at 4 d postinfection and showing typical CPE induced by birnavirus infection. (D) Cell culture infected with IPNV reference strain Erwin at $3 \mathrm{~d}$ post-infection and showing typical CPE induced by IPNV infection. Scale bars $=100 \mu \mathrm{m}$

sage in CHSE-214 cell cultures but the appearance of CPE occurred earlier as the number of passages increased. Virus isolated from the index case (isolate number 980047) was stored at $-80^{\circ} \mathrm{C}$ and used for subsequent characterisation.

\section{Other fish samples}

Following the initial isolation of aquatic birnavirus from the index case, extensive sampling and testing of farmed and wild fish was undertaken during 1998. Table 1 summarises the results of virological examination performed on these samples. Samples were only considered virus-positive if they had yielded CPE in cell culture and these cell cultures were immunoperoxidase test positive and/or positive by electron microscopy (EM) and/or positive by PCR analysis. All isolates had been stored at $-80^{\circ} \mathrm{C}$. Aquatic birnavirus was isolated from samples obtained from fish, either farmed or wild, obtained from within Macquarie Harbour only. Even though the sample sizes were small, 4 out of 10 species of wild fish sampled were positive for aquatic birnavirus. Reovirus was only isolated from farmed Atlantic salmon obtained from sites outside Macquarie Harbour.

\section{Electron microscopy}

\section{Negative contrast electron microscopy}

The original samples of cell culture material (from the index case) contained birnavirus particles. The viruses were non-enveloped, icosahedral, and approximately $60 \mathrm{~nm}$ in diameter (Fig. 4A). Tubules (approximately $70 \mathrm{~nm}$ in diameter) were also observed (Fig. 4B). In addition, supernatant fluids from CHSE- 
Table 1. Surveillance of Tasmanian fish stocks for salmonid viruses: 1998 results summary. Samples were taken as described in 'Materials and methods'. Each submission could consist of 1 or more tissue pools which could originate from 1 or more fish (up to 10). Each submission could include samples from different fish species. The table shows the results for each pool tested during 1998 calendar year. Tissue pools were considered positive (+ve) for virus (either aquatic birnavirus [ABV] or Atlantic salmon reovirus) if they were culture positive (cultures show typical CPE) and virus was identified by immunoperoxidase test and/or electron microscopy examination and/or PCR analysis. Samples obtained from inside Macquarie Harbour (MH) are distinguished from samples obtained from outside the harbour

\begin{tabular}{|c|c|c|c|c|}
\hline \multirow{2}{*}{ Species sampled } & \multirow{2}{*}{ Location } & \multirow{2}{*}{$\begin{array}{l}\text { No. of } \\
\text { pools }\end{array}$} & \multicolumn{2}{|c|}{ Results } \\
\hline & & & $\begin{array}{l}\text { ABV } \\
+ \text { ve }\end{array}$ & $\begin{array}{l}\text { Reovirus } \\
+ \text { +ve }\end{array}$ \\
\hline \multirow[t]{2}{*}{ Atlantic salmon } & Inside MH & 39 & 11 & 0 \\
\hline & Outside MH & 254 & 0 & 40 \\
\hline \multirow{2}{*}{ Rainbow trout } & Inside $\mathrm{MH}$ & 68 & 10 & 0 \\
\hline & Outside MH & 106 & 0 & 0 \\
\hline \multirow{2}{*}{$\begin{array}{l}\text { Wild brown } \\
\text { trout }\end{array}$} & Inside $\mathrm{MH}$ & 7 & 0 & 0 \\
\hline & Outside MH & 18 & 0 & 0 \\
\hline \multirow[t]{2}{*}{ Flounder } & Inside $\mathrm{MH}$ & 4 & 2 & 0 \\
\hline & Outside MH & 1 & 0 & 0 \\
\hline Spiked dogfish & Inside $\mathrm{MH}$ & 2 & 2 & 0 \\
\hline Ling & Inside $\mathrm{MH}$ & 3 & 1 & 0 \\
\hline \multirow[t]{2}{*}{ Cod } & Inside $\mathrm{MH}$ & 3 & 2 & 0 \\
\hline & Outside MH & 3 & 0 & 0 \\
\hline Skate & Inside MH & 3 & 0 & 0 \\
\hline Blue grenadier & Inside $\mathrm{MH}$ & 3 & 0 & 0 \\
\hline Brook trout & Outside $\mathrm{MH}$ & 6 & 0 & 0 \\
\hline Others (3) & Inside $\mathrm{MH}$ & 3 & 0 & 0 \\
\hline
\end{tabular}

214 cell cultures inoculated with tissue homogenates from other Atlantic salmon Salmo salar and rainbow trout Oncorhynchus mykiss were examined. Birnaviruses were identified in 15 different samples from Atlantic salmon and 9 different samples of rainbow trout. No birnaviruses were observed in supernatant fluids from uninfected CHSE-214 cell cultures. When the viruses were incubated with antibody raised against IPNV serotype $\mathrm{Ab}$ and protein $\mathrm{A}$-gold, the viruses and tubules were labelled (Fig. 4B).

\section{Examination of ultrathin sections of pancreas from original fish}

Examination of ultrathin paraffin sections containing pancreatic tissue of the index fish revealed the presence of $60 \mathrm{~nm}$ particles (Fig. 5A). These particles were icosahedral, containing electron-dense cores, and were specifically gold-labelled in adjacent LR White sections following incubation with the reference anti-IPNV antiserum (Fig. 5B).

\section{Examination of ultrathin sections from infected CHSE-214 cells}

Infected cells possessed cytoplasmic icosahedral viruses. The viruses were distributed as single particles or were present as intracellular aggregates. Virus-associated tubules were also present within the cytoplasm (Fig. 6). There was no evidence of virus budding. Viruses were sometimes observed within membranebound vesicles. Examination of a section containing a
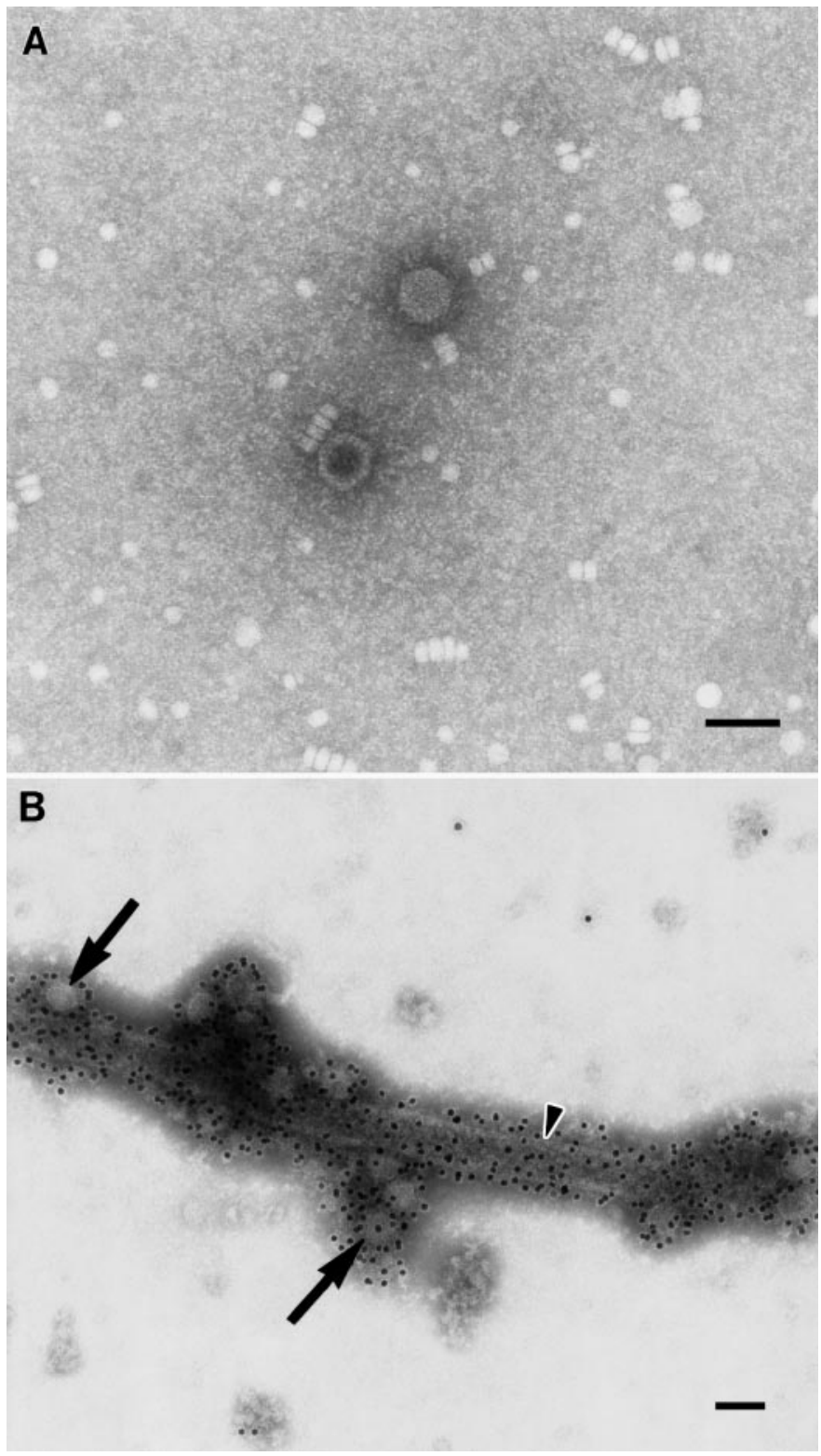

Fig. 4. Transmission electron micrographs of (A) aquatic birnaviruses and (B) gold-labelled aquatic birnaviruses and associated tubules. All preparations have been negatively stained with phosphotungstic acid. (B) Large arrows indicate the location of virus particles and arrowheads the location of a virus tubule. Scale bars $=100 \mathrm{~nm}$ 
region of the pancreas (sampled from the index fish) revealed the presence of icosahedral viruses similar to those identified within infected CHSE-214 cells.

The above data show that the virus isolated in cell culture belongs to the family Birnaviridae, belongs to the genus Aquabirnaviridae, was ultrastructurally and antigenically similar to virus identified in the index fish, and is related to IPNV.

\section{Virus neutralisation}

Both virus preparations (IPNV, reference strain $A b$, and the Macquarie Harbour isolate 980047 from the index case) were neutralised by the rabbit polyclonal anti-IPNV serotype Ab antiserum and by the pan-specific antiIPNV monoclonal antibody, AS1. The neutralising titre of monoclonal antibody AS1 for both viruses was approximately $10^{-4}$. These results identified the Macquarie Harbour isolate 980047 as an aquatic birnavirus. The neutralising titre of the polyclonal rabbit antiserum was approximately $10^{-6}$ for the homologous IPNV serotype $\mathrm{Ab}$ isolate but was approximately $10^{-4}$ for isolate 980047 , indicating that these viruses were related but not identical. Neither virus was neutralised by either NRS or the nonneutralising monoclonal antibody E5.

\section{Immunoperoxidase tests}

\section{Tissue sections}

No specific staining was observed in negative control sections, and all positive control sections showed a clear positive reaction (results not shown). The sections originating from the Tasmanian Atlantic salmon produced a strong positive reaction when incubated with the hyperimmune IPNV serotype Ab antiserum (Fig. 7). No reaction was observed using other antisera specific for the salmonid viral pathogens viral haemorrhage septicaemia virus (VHSV) and infectious haematopoietic necrosis virus (IHNV) (results not shown).

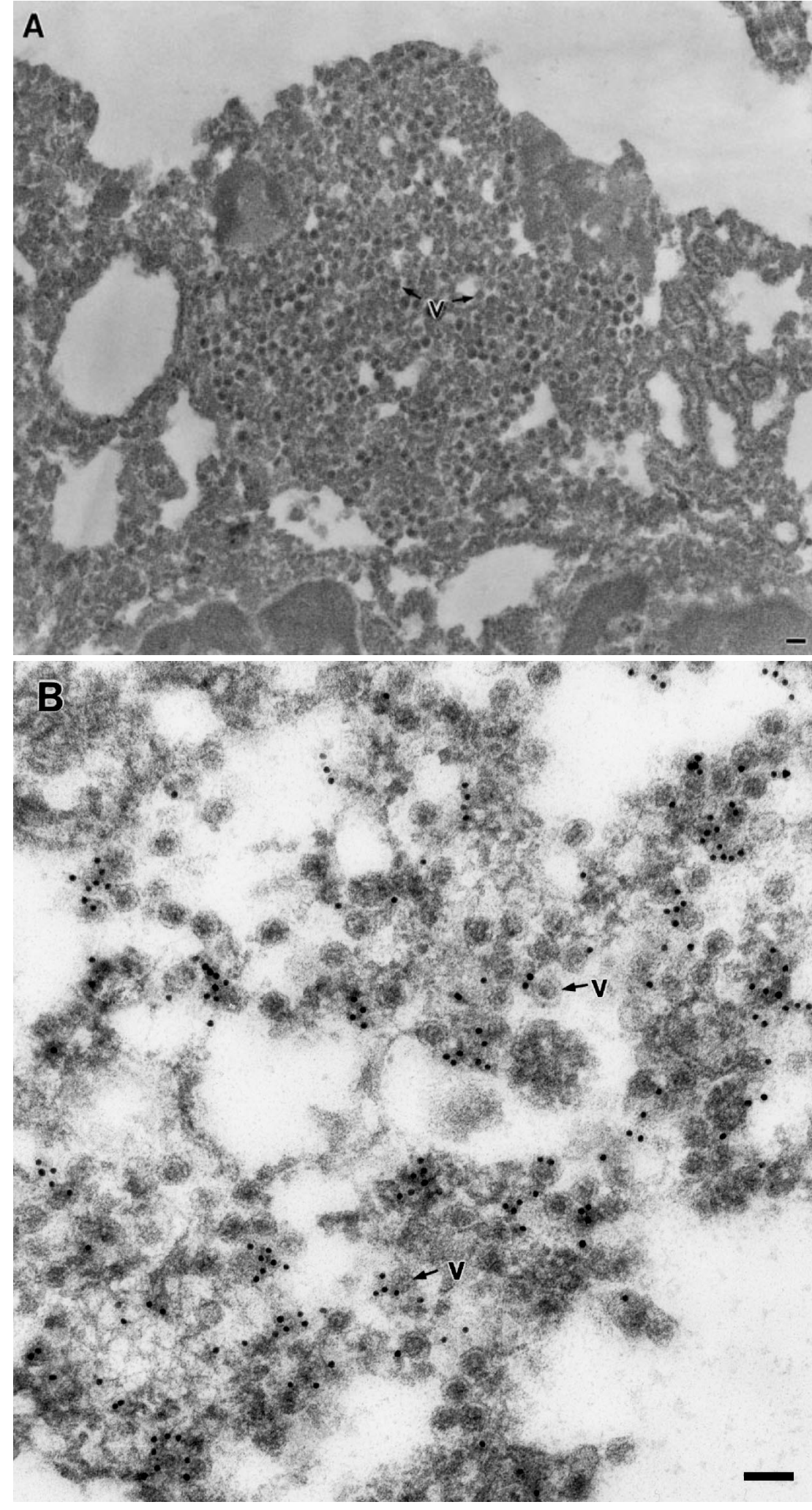

Fig. 5. Transmission electron micrographs of (A) an ultrathin section, derived from a $12 \mu \mathrm{m}$ paraffin section of pancreatic tissue from the index case. (B) LR White sections, from the same tissue block, that have been incubated with the reference anti-IPNV serotype $\mathrm{Ab}$ antiserum and protein A-gold. Viruses (v). Scale bars $=100 \mathrm{~nm}$ 


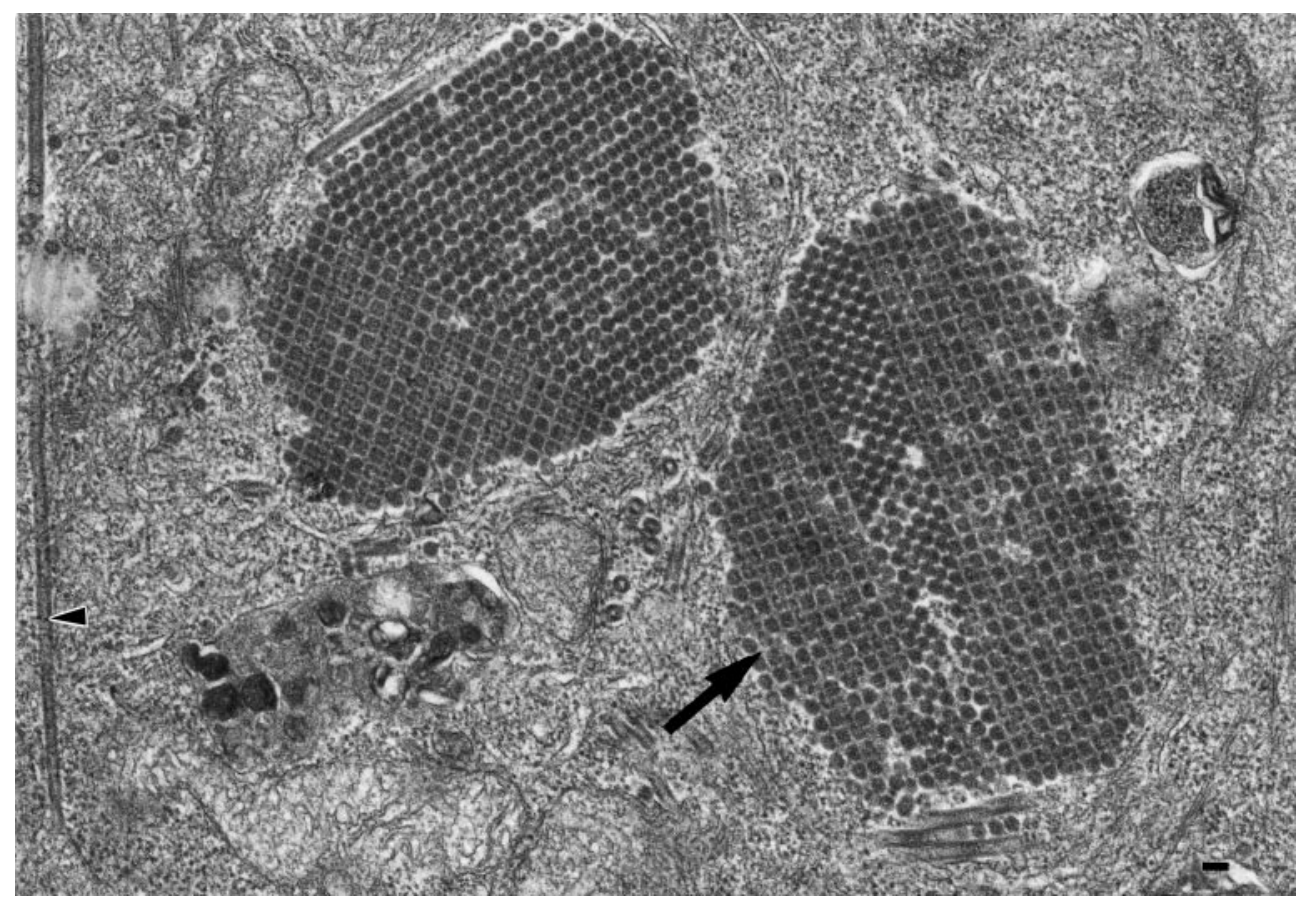

Fig. 6. Transmission electron micrograph of a CHSE-214 cell infected with Macquarie Harbour aquatic birnavirus. The virus aggregates/crystals are located within the cytoplasm (arrow) as are the viral tubules (arrowhead). Scale bar $=100 \mathrm{~nm}$

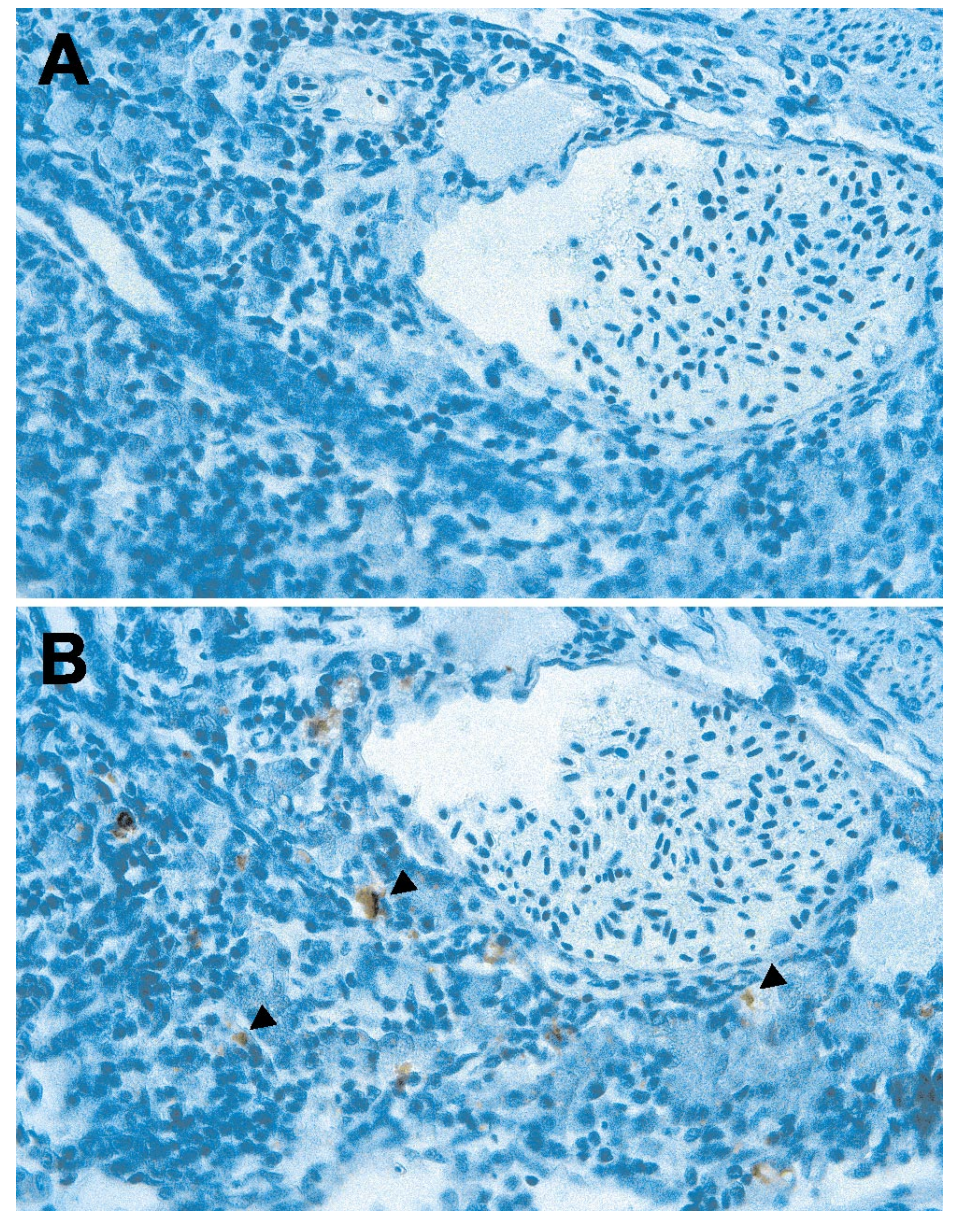

\section{Cell cultures}

All positive and negative control cultures reacted as expected (results not shown). Cell cultures inoculated with tissue samples from the original 'pinhead' fish, and which displayed CPE, stained positively with the IPNV serotype $\mathrm{Ab}$ antiserum (Fig. 8).

Subsequent testing has shown that cell cultures, infected with the Macquarie Harbour isolate, react with the pan-specific monoclonal antibodies AS1, E1 and E5 which appear to react with highly conserved epitopes of aquatic birnaviruses (Caswell-Reno et al. 1989). Preliminary serotype analysis using a series of monoclonal antibodies (available from DiagXotics Inc.) is shown in Table 2. Reactivity to monoclonal antibodies in this immunoperoxidase test was dependent on the time postinfection at which cultures were fixed for sub-

Fig. 7. Photomicrographs of tissue (pancreas) sections derived from the index case. Tissue sections were processed for the immunoperoxidase test as described in 'Materials and methods'. (A) Pancreas section reacted with normal rabbit serum. (B) Pancreas section from the same tissue block reacted with hyper-immune anti-IPNV antiserum. Arrowheads point to examples of the positive reaction demonstrating the presence of birnavirus 


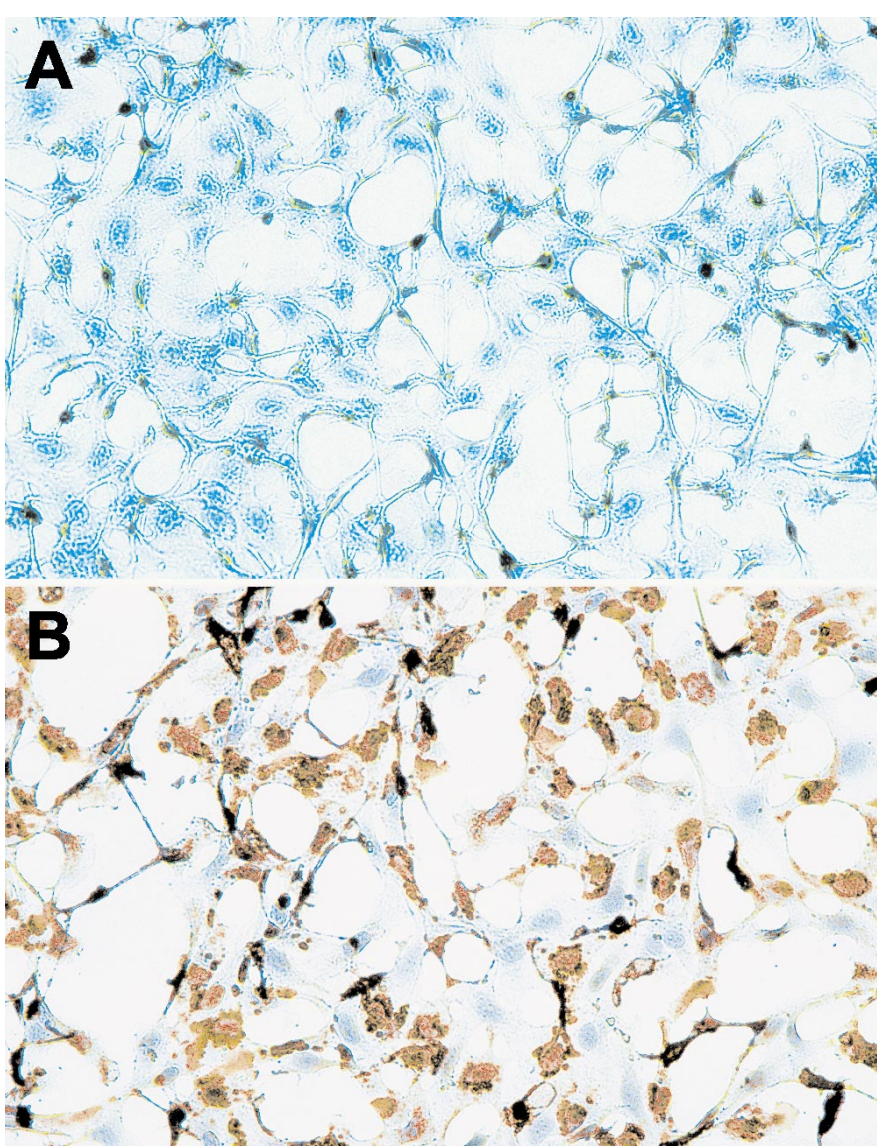

Fig. 8. Photomicrographs of CHSE-214 cell cultures infected with virus isolate 980047 . Cultures were processed for immunoperoxidase test as described in 'Materials and methods'. (A) Infected culture, $2 \mathrm{~d}$ post-infection and reacted with normal rabbit serum. The same result was observed when infected cultures were reacted with either hyper-immune anti-IHNV or anti-VHSV antisera (results not shown). (B) Infected culture, 2 d post-infection and reacted with hyper-immune anti-IPNV antiserum. Note the positive reaction in (B) only demonstrating the presence of birnavirus. Although CPE is not evident at this early stage of viral infection, virus is localised in the majority of cells

sequent testing. Reference strains VR299, Sp, Ab and Erwin (obtained from Drs B. Hill and K. Way, CEFAS, Weymouth, UK) were used for comparison. The Macquarie Harbour isolate does not react with W4 or W5 (VR-299 serotype-specific) antibodies or with E2 (Ab serotype-specific) antibody nor does it display a reaction pattern typical of $\mathrm{Sp}$ serotypes. Interestingly, in the immunoperoxidase test on fixed cells performed here, Sp serotype yielded a strong positive reaction with W4 antibody which is in contrast to other results (Caswell-Reno et al. 1989).

\section{Western blot analysis}

Sera raised against IHNV, VHSV and Tasmanian aquareovirus and the preimmune negative control sera failed to produce any reaction (results not shown). The only antiserum to produce any reaction in Western blots was that directed towards IPNV serotype Ab (Fig. 9). No cross-reaction was observed in the cell control lane (lane 2). In general, the pattern of reactivity displayed by isolate 980047 in Western blot was very similar, but not identical, to that observed with the 3 IPNV serotypes. Densitometry revealed that all the viral isolates produced relatively complex patterns of reactivity. The banding pattern observed broadly consisted of 3 groups of bands containing numerous minor bands: the first, above $100 \mathrm{kDa}$, the second group of 3 bands around $50 \mathrm{kDa}$, and a third group of bands around $32 \mathrm{kDa}$ which contained the most prominent staining. There was variation observed between the patterns obtained with the 3 IPNV serotypes. Computer analysis of the blot of isolate 980047 revealed 13 bands ranging in apparent molecular weight from 29 to $155 \mathrm{kDa}$. Of these, a single band of $32.2 \mathrm{kDa}$ was the most prominent. All 3 IPNV reference isolates also displayed a prominent band around $32 \mathrm{kDa}$. While there was some variation in the calculated molecular weights for these: $\mathrm{Ab}(32.0 \mathrm{kDa}), \mathrm{Sp}(31.4 \mathrm{kDa})$ and VR-299 $(31.7 \mathrm{kDa})$, the pattern of antibody reactivity of isolate 980047 in this region appeared very similar to that of the Ab serotype.

\section{PCR analysis}

Nucleotide sequence analysis of the PCR amplified fragment (459 bp) from the $\mathrm{MH}$ isolate identified a high degree of homology with IPNV isolates (76-91\%). However, when the deduced amino acid sequences of the polypeptides encoded for by these RNA sequences were compared, homology increased to 90-96\%. A phylogenetic comparison between the deduced poly-

Table 2. Serotyping IPNV/birnaviruses using monoclonal antibodies. CHSE214 cell cultures were infected with the virus strains shown and processed for the immunoperoxidase test as described in 'Materials and methods'. Positive (+) and negative $(-)$ reactions with the series of birnavirus-specific monoclonal antibodies obtained from DiagXotics Inc. are shown

\begin{tabular}{|lcccccccccccc|}
\hline Isolate & AS1 & W1 & W2 & W3 & W4 & W5 & E1 & E2 & E3 & E5 & E6 \\
\hline VR-299 & + & - & - & + & + & + & + & - & - & + & + \\
Sp & + & - & - & + & + & - & + & - & - & + & - \\
Ab & + & + & + & - & - & - & + & + & - & + & + \\
Erwin & + & - & + & + & + & + & + & - & - & + & + \\
Macquarie Harbour & + & + & + & + & - & - & + & - & - & + & - \\
\hline
\end{tabular}




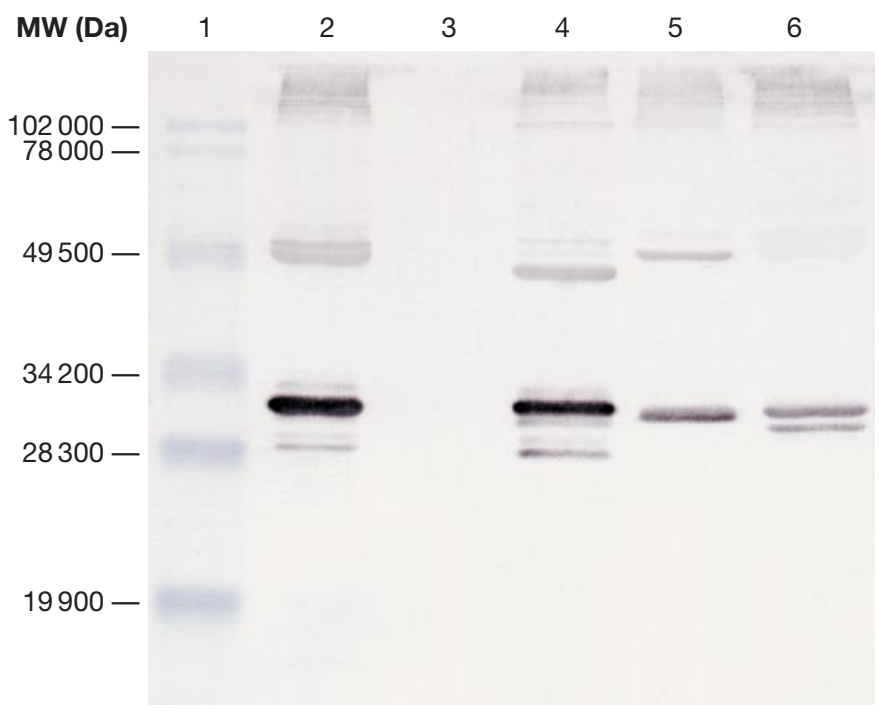

Fig. 9. Western blot comparison of virus isolate 980047 and exotic IPNV serotypes Ab, Sp and VR-299 using pan-specific rabbit anti-IPNV antibody. Lane 1: pre-stained molecular weight (MW) standards, low range (Bio-Rad). Lane 2: virus isolate 980047. Lane 3: cell control (CHSE-214). Lane 4: IPNV Ab. Lane 5: IPNV Sp. Lane 6: IPNV VR-299

peptide coded for by the amplified PCR DNA fragment of $\mathrm{MH}$ isolate and other known IPNV isolates was carried out. The results (Fig. 10) show a high degree of homology with the N1 and Fr-21 isolates of IPNV (Havarstein et al. 1990, Heppell et al. 1995).

\section{DISCUSSION}

The Tasmanian Salmonid Health Surveillance Program is a cooperative activity involving all sectors of the Tasmanian salmonid aquaculture industry, the Tasmanian State Department of Primary Industries, Water and Environment (DPIWE) and CSIRO Livestock Industries. The program involves regular farm inspections by DPIWE staff who advise farm operators on fish health matters and who also collect samples on a routine or opportune basis for histopathology and bacteriology testing, undertaken by State DPIWE laboratories at Kings Meadows, and virology testing, undertaken by the Australian Animal Health Laboratory (AAHL) CSIRO Livestock Industries, Geelong.

Histological examination of the original opportune samples revealed pancreatic lesions suggestive of an infectious aetiology. Pancreatic lesions, related to fat necrosis or a diffuse increase in cellularity due to fat catabolism, are not unusual in pinhead fish. However, the observed lesions of a mixed mononuclear inflammatory component which involved the pancreatic acini in at least 1 fish had not been observed previously in samples of Tasmanian salmonids. This observation prompted immediate submission of samples to AAHL for virological examination.

Within a month of submitting samples to AAHL, an aquatic birnavirus had been isolated in cultures of fish cell lines. The virus reacted, in a variety of immunoassays, with antibodies raised against IPNV and contained nucleic acid sequences closely related to IPNV isolates. Based on these results, farmed fish movements from Macquarie Harbour to other marine sites were banned and further sampling within the harbour was undertaken. Subsequent sampling of other farmed and wild fish species in Macquarie Harbour has shown that the birnavirus was present in farmed Atlantic salmon and rainbow trout at 2 sites and in flounder Rhombosolea tapirina, cod Pseudophycis sp., spiked dogfish Squalus megalops and ling Genypterus blacodes. Other wild fish sampled in small numbers within Macquarie Harbour (Table 1) include blue grenadier Macruronus novaezelandiae and morwong Nemadactylus sp. These samples have been negative.

During this time, extensive testing of Tasmanian salmonid populations has demonstrated all hatcheries and all marine farms outside of Macquarie Harbour to

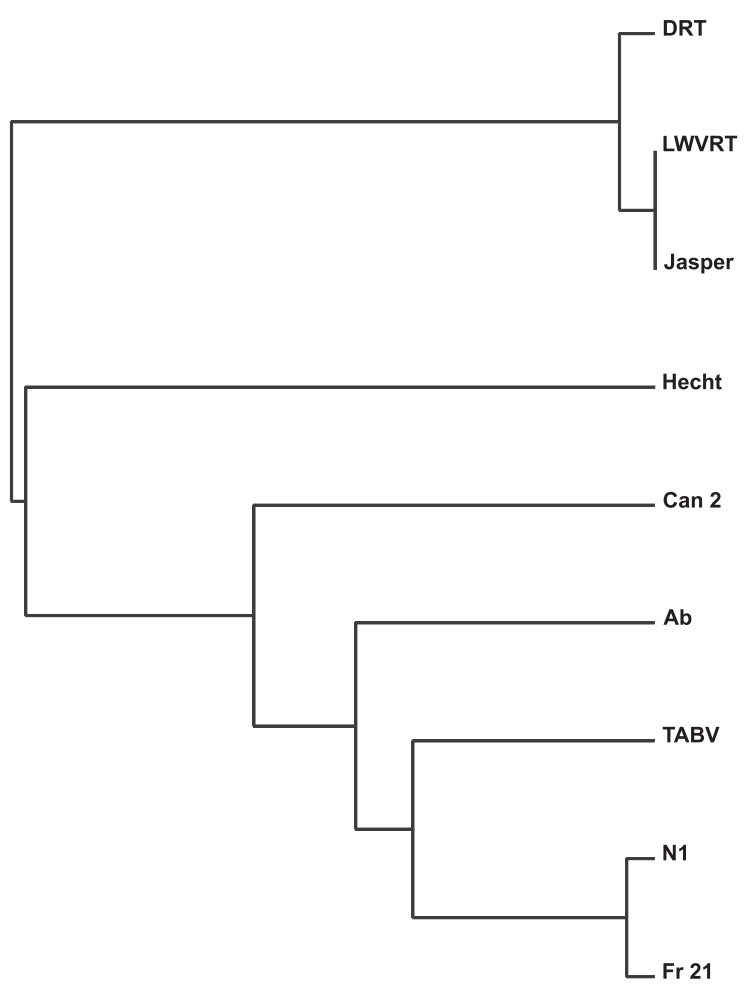

Fig. 10. Phylogenetic comparison of the Tasmanian aquatic birnavirus MH isolate (TABV) and other birnavirus/IPNV isolates. IPNV isolates with GenBank accession numbers (given in brackets) were as indicated: DRT (D26526 and D26527); LWVRT (L40584); Jasper (L13984); Hecht (L40583); Canada 2 (L40581); Ab (L40580); N1 (D00701); Fr21 (L40582) 
be free of birnaviruses (Table 1), suggesting that the birnavirus has entered Macquarie Harbour via wild fish populations. However, the precise origin and the time of introduction are not known. Testing of aquatic invertebrates has not been undertaken to date. All testing has been carried out using the CHSE-214 cell line, which appears to be the most sensitive cell line for this IPN-like virus. Any abnormalities observed in inoculated cultures have been followed up by examination using electron microscopy, immunoperoxidase and/or PCR tests. To date there has been good correlation between the different tests used during this investigation.

Western blot analysis showed that isolate 980047 was serologically related to the reference isolates of IPNV. The multiple bands in the Western blots around $50 \mathrm{kDa}$ are consistent with the size of 50 to $54 \mathrm{kDa}$ previously reported for the major capsid protein of IPNV VP2 (Christie et al. 1988, Estay et al. 1990). In virusinfected cells, VP2 is present in 'minor quantities' but is accompanied by its precursor proteins, which probably accounts for the multiple bands observed in this region. The intense reaction and multiple bands observed at around $32 \mathrm{kDa}$ is consistent with the molecular weight of $31 \mathrm{kDa}$ previously reported for VP3 (Christie et al. 1988). The underlying relatedness of isolate 980047 with the IPNV isolates was further reinforced by both the similarity of the distribution of peptides recognised by the IPNV antisera and also the relative staining intensity of bands at around $32 \mathrm{kDa}$. While it was not possible to accurately assign molecular weights to specific bands by Western blotting alone, clear differences in apparent molecular weight of the most prominent band clearly showed that isolate 980047, although more closely related to the $\mathrm{Ab}$ serotype, was not identical to any of the exotic reference IPNV isolates compared.

In addition, it has been further shown that the Macquarie Harbour isolate has a unique pattern of reactivity with the series of monoclonal antibodies used in this study. Based on the immunoperoxidase test results obtained here, and on other published data (CaswellReno et al. 1989), the Macquarie Harbour isolate 980047 cannot be clearly assigned to any of the major serotypes of IPNV. Further work is required in order to assign serotype classification. Interestingly, phylogenetic analysis undertaken on the RNA coding sequences of the $\mathrm{MH}$ isolate shows close identity with known IPNV isolates and, in particular, with those of the N1 and Fr-21 isolates and the Ab reference strain. This analysis was undertaken using limited nucleic acid sequence data and further sequencing and analysis are required to confirm these relationships.

Although it has been demonstrated that the virus can be transmitted experimentally to 10 mo old Atlantic salmon and rainbow trout (results not shown), pathogenicity studies (cf. McAllister \& Owens 1986, 1995 Taksdal et al. 1997) could not be undertaken at the time of virus isolation, due to the lack of appropriately aged fish (Dorson \& Torchy 1981). It is interesting to note that aquatic birnavirus(es) has/ve been isolated on a regular basis from salmonids in New Zealand (Tisdall \& Phipps 1987, Anderson 1995), and similar to the occurrence in Tasmania, there were no signs of overt disease (Anderson 1996, 1998). Moreover, the virus isolated from New Zealand fish was also shown to be related to IPNV serotype Ab (Tisdall \& Phipps 1987). Further work is required to confirm that the Macquarie Harbour isolate is non-pathogenic to salmonids and to determine any relationship to the New Zealand strain.

The Tasmanian salmonid industry has been operating for approximately $15 \mathrm{yr}$ and has not suffered losses due to viral diseases. The presence of this virus in salmonid stocks in Tasmania, even though it appears to be non-pathogenic, will have a negative economic impact. It is likely that this virus will be isolated again during routine surveillance, and it is now necessary to develop tests which will distinguish between this isolate/strain and other IPN-like (non-pathogenic) or IPN (pathogenic) viruses. The use of monoclonal antibodies and/or PCR-based tests should facilitate such differentiation but with an added cost to the surveillance program.

Given that the salmon has had a 20 yr history of virological testing, although not proven, it is most likely that the aquatic birnavirus entered Macquarie Harbour via wild fish populations. It is possible that, due to their poor condition, pinhead fish are more susceptible to infection than normal fish; they provide sites for pathogen replication and thus it would be prudent management to cull these unproductive fish from farmed populations. While the time of introduction is not known, the regular sampling program has demonstrated that the infection has only recently become established in salmonids farmed in the harbour. Prompt diagnosis has prevented spread of the virus to other areas, such as freshwater hatcheries through farmed fish movements. There are a number of salmonid pathogens which can be carried by wild fish, and the present discovery would indicate that monitoring of wild fish around aquaculture marine sites is warranted. Although such monitoring is unlikely to prevent entry of infectious agents, it will provide knowledge concerning potential pathogens and allow farm operators to modify practices accordingly.

Acknowledgements. The authors thank Mr F. Filippi (CSIRO Australian Animal Health Laboratory) for his expert assistance with photomicrography and graphic design. 


\section{LITERATURE CITED}

Anderson CD (1995) Surveillance for fish diseases. Surveillance 22(4):13

Anderson CD (1996) Distribution of salmonid diseases in New Zealand. Surveillance 23(4):23-24

Anderson CD (1998) Survey of New Zealand salmonids for OIE List B viruses. Surveillance 25(4):9-10

Caswell-Reno P, Lipipun V, Reno PW, Nicholson BL (1989) Use of a group-reactive and other monoclonal antibodies in an enzyme immunodot assay for identification and presumptive serotyping of aquatic birnaviruses. J Clin Microbiol 27:1924-1929

Christie KE, Havarstein LS, Djupvik HO, Ness S, Endresen C (1988) Characterisation of a new serotype of infectious pancreatic necrosis virus isolated from Atlantic salmon. Arch Virol 103:167-177

Dorson M, Torchy C (1981) The influence of fish age and water temperature on mortalities of rainbow trout, Salmo gairdneri Richardson, caused by a European strain of infectious pancreatic necrosis virus. J Fish Dis 4:213-221

Estay A, Farias G, Soler M, Kuznar J (1990) Further analysis on the structural proteins of infectious pancreatic necrosis virus. Virus Res 15:85-96

Felsenstein J (1989) Phylip 3.2 manual. University of California, Herbarium, Berkley, CA

Fijan N, Sulimanovic D, Bearzotti M, Muzinic D, Zwillenberg LO, Chilmonczyk S, Vautherot JF, de Kinkelin P (1983) Some properties of the epithelioma papulosum cyprini (EPC) cell line from carp Cyprinus carpio. Ann Virol (Inst Pasteur) 134E:207-220

Havarstein LS, Kalland KH, Christie KE, Endresen C (1990) Sequence of the large double stranded RNA segment of the N1 strain of infectious pancreatic necrosis virus: a comparison with other Birnaviridae. J Gen Virol 71:299-308

Heppell J, Tarrab E, Lecomte J, Berthiaume L, Arella M (1995) Strain variability and localization of important epitopes on the major structural protein (VP2) of infectious pancreatic necrosis virus. Virology 214:40-49

Editorial responsibility: Jo-Ann Leong,

Corvallis, Oregon, USA
Hill BJ, Way K (1995) Serological classification of infectious pancreatic necrosis (IPN) virus and other aquatic birnaviruses. Annu Rev Fish Dis 5:55-77

Hyatt AD (1989) Protein A-gold: nonspecific binding and cross-contamination. In: Hayat MA (ed) Colloidal gold: principles, methods and applications, Vol 2. Academic Press, San Diego, p 19-31

Hyatt AD (1991) Immunogold labelling techniques. In: Harris JR (ed) Electron microscopy in biology: a practical approach. IRL Press, Oxford, p 59-80

Laemmli UK (1970) Cleavage of structural proteins during the assembly of the head of bacteriophage T4. Nature 227: 680-685

McAllister PE, Owens WJ (1986) Infectious pancreatic necrosis virus: protocol for a standard challenge to brook trout. Trans Am Fish Soc 115:466-470

McAllister PE, Owens WJ (1995) Assessment of the virulence of fish and molluscan isolates of infectious pancreatic necrosis virus for salmonid fish by challenge of brook trout, Salvelinus fontinalis (Mitchill). J Fish Dis 18:97-103

OIE (1997) Diagnostic manual for aquatic animal diseases, 2nd edn. Office International des Epizooties, Paris

Taksdal T, Stangeland K, Dannevig BH (1997) Induction of infectious pancreatic necrosis (IPN) in Atlantic salmon Salmo salar and brook trout Salvelinus fontinalis by bath challenge of fry with infectious pancreatic necrosis virus (IPNV) serotype Sp. Dis Aquat Org 28:39-44

Tisdall DJ, Phipps JC (1987) Isolation and characterisation of a marine birnavirus from returning quinnat salmon (OnCorhynchus tshawtscha) in the south island of New Zealand. NZ Vet J 35:217-218

Towbin H, Staehelin T, Gordon J (1979) Electrophoretic transfer of proteins from polyacrylamide gels to nitrocellulose sheets: procedure and some applications. Proc Natl Acad Sci USA 76:4350-4354

Whittington RJ, Kearns C, Hyatt AD, Hengstberger S, Rutzou $\mathrm{T}$ (1996) Spread of epizootic haematopoietic necrosis virus (EHNV) in redfin perch (Perca fluviatilis) in southern Australia. Aus Vet J 73:112-114

Submitted: October 13, 1999; Accepted: March 16, 2000

Proofs received from author(s): September 18, 2000 